\title{
A Literature Review of Followership as Independent and Dependent Variables and the Meaning
}

\author{
Herdian Herdian ${ }^{1}$, Ridwan Ridwan ${ }^{2}$, Rias Tusianah ${ }^{3}$, Usastiawaty CAS Isnaini ${ }^{4}$, Sulpakar Sulpakar ${ }^{5}$, \\ M. Arifki Zainar ${ }^{6}$, Sudjarwo Sudjarwo ${ }^{7}$, Hasan Hariri ${ }^{8}$, Albet Maydiantoro, \\ Tubagus Ali Rachman Puja Kesuma ${ }^{10}$, Achril Zalmansyah ${ }^{11}$ \\ ${ }^{1,4,6,7}$ Education Doctor Program, FKIP. Universitas Lampung, Bandar Lampung City, 35141, Indonesia \\ ${ }^{2}$ SMP Negeri 3 Way Pengubuan, Central Lampung Regency, 34164, Indonesia \\ ${ }^{3}$ SMP Negeri 1 Simpang Agung, central Lampung Regency, 34164, Indonesia \\ ${ }^{4,6}$ Department of Nursing Management, Universitas Malahayati, Bandar Lampung City, 35141, \\ Indonesia \\ ${ }^{9}$ Department of Economic Education, FKIP Universitas Lampung, Bandar Lampung City, 35141, \\ Indonesia \\ ${ }^{10}$ IAIN Metro, Metro City, Lampung Province, 34111, Indonesia \\ ${ }^{11}$ Badan Riset dan Inovasi Nasional, Gedung B.J. Habibie, Lt 21 Jl. M.H. Thamrin No 8 Jakarta Pusat
}

Received: June 9, 2021. Revised: December 10, 2021. Accepted: December 26, 2021. Published: January 26, 2022.

\begin{abstract}
This article is a literature review. This study aims to critically as well as comprehensively analyze engagement as an independent $(X)$ and dependent $(Y)$ variable. There are 15 articles that were reviewed with quantitative criteria and influence. The outcomes of this investigation found that the average followership score in the role of the $X$ variable was 0.3957 , in the 3rd class interval, which was between $0.323-0.414$ with a fairly low category. While the average follow-up score as the $Y$ variable is 0.385833 , which is in the 4th class interval, which is between $0.379-0.501$ in the high category. Based on the findings, the authors conclude that (1) followers as variable $X$ have characteristics that are proactive, critical of the situation that occurs in their organization, dare to express their views, and criticize the leadership for the good and success of the organization to which they are affiliated, scores that are in the low enough category range indicate to the reader that follower participation has not received attention from the leader to be given more space to contribute or because followers are generally the party being thought of, they think they don't need to think because someone has already thought about it, (2) follower, as a $\mathrm{Y}$ variable is characterized by that followers, are the party who thought so that he only needs to be obedient, committed, perform well so that the leader provides opportunities to continue to grow with his organization and continue to develop his competence to complete his duties through training designed by the leade.
\end{abstract}

Keywords- followership, influence, independent variable, dependent variable.

\section{INTRODUCTION}

$\mathrm{L}$ EADERS and followers are dynamic functions, and parts people all play at diverse times in their occupations [1,2]. They are like two sides of a coin that cannot be separated [3], each dynamically linked to the other [4]. Followers are a reflection of leadership [5] and leaders need followers to implement their strategies [6]. Without followers, leaders will become schizophrenics who sit and talk to themselves in their offices [7], therefore in teamwork, managers and followers are together important in determining the success of an organization [8].

Members or followers take part in an active role in the leadership function for at least two reasoning: 1) without followers, no one can become a leader; 2) all leaders are sometimes followers [9]. As a result, organizational thinkers are more and more focusing on leaders as well as on followers [10-12] and on work settings/contexts [13] which may have a moderate influence on the connection between followers and mindsets in carrying out their roles.

Since Kelley [14] argued that about $80 \%$ of organizational triumph can be credited to followers as published in the textbook The Power of Followership, appreciation of followers as a meaningful component of the leadership function is gaining momentum [15-21]. This unlocks the gate for 
leadership study to acknowledge the useful opportunities of problems and theories from a follower's viewpoint [11].

Although followership as part of organizational studies has been recognized and has made valuable contributions [22], even the research trends of the last decade published in research articles, proceedings, master's theses and even doctoral dissertations have also begun to discuss membership in various fields, ranging from education [23-28], industry and companies [29-37], military field [33, 38-46], military field $[47,48]$, hospitality industry [15], bidang industri perhotelan [32], public administration [49], management systems and business [50], banking, telecommunications and transportation [39], and other fields. However, reviews that try to find out the highest average score of followership from various research documents and implied scores are still very minimal and have not even been published in reputable journals.

Considering these reasons, this article seeks to fill the research crack by providing a deeper knowledge of the function of followership within the group. To be effective, the writer asks the question, "What is the average score for followership as the independent $(\mathrm{X})$ and dependent $(\mathrm{Y})$ variables, and the implied meaning of the scores obtained?".

\section{II.METHOD}

The primary reference for this review is the SCOPUS database. The beginning tracking strategy utilized the one word [followership] but was extended to incorporate the term [followership and leadership] when the beginning tracking did not find a match. The rationale for this all-encompassing search strategy is that a little number of studies related to followership were specified by the authors during the initial search. Given the lack of studies found in the beginning track, the search strategy was expanded beyond the SCOPUS database. A search was performed on the GOOGLE SCHOLAR database using the term [followership]. Reference lists for each review article found in the beginning tracking, as well as citations from eligible studies, were considered for additional studies.

Articles that meet the requirements are then evaluated for an assessment of the use of an assessment tool, which is deliberately made based on the author's assessment standards, namely (1) The article discusses followership either as the independent variables $(\mathrm{X})$ or dependent variables $(\mathrm{Y})$; (2) Discard articles that discuss followership outside of influences such as relationships, closeness and/or direction of relationships only. This allows the authors to examine the main study in-depth and ascertain its relevance and functionality. To increase accuracy, the main study was independently evaluated by the analysis teammates (authors two, three, and four), and differences in areas of opinion were discussed. If ambiguity persists, teammates (authors five, six, seven) perform more judgments to reach a final settlement among the analysis teammates.

The author examines articles that focus on the results of followership calculations on two types of variables, namely as an independent variable $(\mathrm{X})$ and as an independent variable
$(\mathrm{Y})$, and retesting or measuring followership from various countries. The articles work in the field and come from the Health sector industry/South Africa, Barge Repair Service/Indonesia, Faculty at an urban public university/United States, Sales Marketing Team Members of Pharmaceutical Companies/Taiwan, Leadership Practice/Pakistan, Followership Behavior US Office of Personnel Management/US, The Followership/Pakistan, diverse industries and with various job types/China, Public administration/USA, Individuals' Followership Behaviors/China, Health (nurse)/Italy, Private Enterprises/ China, Energy Supplier/ Portugal, University students/Korea, and Kostrad (Indonesian Armed Forces). The author through the Scopus and Google Scholar databases got the article from the Journal of Psychology in Africa, International Journal of Marine Engineering Innovation and Research, International Journal of Marine Engineering Innovation and Research, Review of Public Personnel Administration, Journal of Career Development, NUML International Journal of Business \& Management, International Journal of Public Sector Management, Journal of Management \& Organization, International Review of Administrative Article, Asian Bus Manage, PLoS ONE, Employees' workplace behaviors, Business Administration and Management, MDPI Sustainability, Management Science Letters.

The selected follower documents were then extracted from the appropriate studies and organized. The data fields taken are as follows: research title, author's name, field of research, country where the research was conducted, year of research, and followership score as the independent variable $(\mathrm{X})$ or dependent variable $(\mathrm{Y})$. The tabulation of the characteristics of the research data and the measurement of the selected articles are presented in Table 1.

The author also analyzed the data obtained from statistical calculations on each sheet of followership documents from selected journal articles. By using each followership data as the independent variable $(\mathrm{X})$ and the dependent variable $(\mathrm{Y})$, the writer then performs calculations to make a tabulation of the reference for the decoding of the mean score of followership as the independent variable (X) (Table 2) and the matrix for the interpretation of the mean value of followership as a variable. dependent $(\mathrm{Y})$ (Table 3).

\section{RESULT}

The initial search for the word [followership] in the SCOPUS database with the limitation of articles published in the last 5 years yielded 634 documents. Of these, 36 articles were selected after the screening of titles and abstracts. After a full-text review, 12 articles were obtained (articles in sequence $1-12$ in table 1) in accordance with the focus of the discussion on this literature review. The search was expanded by searching for the word [followership] in the GOOGLE SCHOLER database with a limitation of articles published in the last 5 years. This search yielded 124 documents, with 17 articles selected after the title and abstract screening. After a 
full-text review, 3 articles were obtained (articles serial number 13 - 15 in table 1 ) according to the criteria. A total of 15 articles were selected after an iterative process. The search results are presented in fig. 1 .

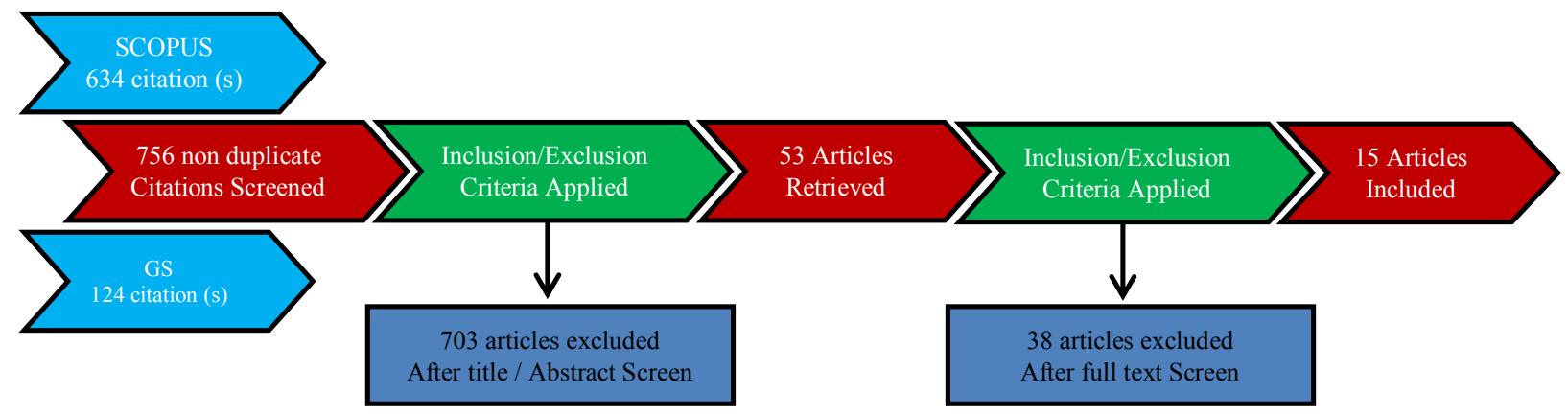

Figure1. Summary of search results regarding followership

A search of the word [leadership] also on the SCOPUS database was performed yielding 124,607 unfiltered documents on leadership themes, compared with 634 unfiltered citations on followership themes from our beginning tracking. Therefore, there is an average of 1 paper on the theme of followership for every 200 articles on the theme of leadership. This search was conducted to describe the relative paucity of articles on the theme of followership; data is not extracted. This data is supported by [51] who noted that over a period of 19 years from 1990 to 2008 only $14 \%$ of papers contained the term follower in the abstract or title of The Leadership Quarterly. To find out the average value of each component, it is shown in Table 1 below.

Table 1. Characteristics of Research and Measurement Data

\begin{tabular}{|c|c|c|c|c|c|}
\hline \multirow[t]{2}{*}{ NO } & \multirow[t]{2}{*}{ Writer (s) and Year } & \multirow[t]{2}{*}{ Country } & \multirow[t]{2}{*}{ Study Field } & \multicolumn{2}{|c|}{ Score } \\
\hline & & & & $\mathbf{X}$ & $\mathbf{Y}$ \\
\hline \multirow[t]{2}{*}{1} & \multirow[t]{2}{*}{ du Plessis and Boshoff [37] } & \multirow[t]{2}{*}{ South African } & \multirow[t]{2}{*}{ Health sector industry } & 0,16 & 0,62 \\
\hline & & & & & 0,01 \\
\hline \multirow[t]{3}{*}{2} & \multirow[t]{3}{*}{ Jin, McDonald [27] } & \multirow[t]{3}{*}{ United States } & \multirow{3}{*}{$\begin{array}{l}\text { Faculty at an } \\
\text { urban public university/ }\end{array}$} & 0,138 & 0,221 \\
\hline & & & & 0.039 & 0,247 \\
\hline & & & & 0.079 & 0,112 \\
\hline \multirow[t]{2}{*}{4} & \multirow[t]{2}{*}{ Jin, McDonald [33] } & \multirow[t]{2}{*}{ United States } & \multirow{2}{*}{$\begin{array}{l}\text { Followership behavior US Office of Personnel } \\
\text { Management }\end{array}$} & 0,58 & \\
\hline & & & & 0,57 & \\
\hline \multirow[t]{2}{*}{5} & \multirow[t]{2}{*}{ Kong, $\mathrm{Xu}[42]$} & \multirow[t]{2}{*}{ China } & \multirow[t]{2}{*}{ Diverse industries and with various job types } & 0,824 & \\
\hline & & & & 0,856 & \\
\hline \multirow[t]{2}{*}{8} & \multirow[t]{2}{*}{ Gatti, Ghislieri [31] } & & Health (nurse)/ Italia & 0,21 & \\
\hline & & & & 0,10 & \\
\hline 9 & Kong, Xin [43] & & Private Enterprises/ China & 0,17 & \\
\hline & & & & 0,22 & \\
\hline & & & & 0,14 & \\
\hline & & & & 0,19 & \\
\hline 10 & Fontoura and Coelho [44] & Portugal & Energy Supplier & 0,371 & \\
\hline & & & & 0,277 & \\
\hline & & & & 0,370 & \\
\hline & & & & 0,104 & \\
\hline
\end{tabular}


INTERNATIONAL JOURNAL OF EDUCATION AND INFORMATION TECHNOLOGIES

\begin{tabular}{|c|c|c|c|c|c|}
\hline 13 & Pujiastuti, Budiarti [45] & Indonesia & Barge Repair Service & 0,67 & \\
\hline \multirow[t]{5}{*}{14} & Ghias, Hassan [39] & Pakistan & Leadership practice & & 0,40 \\
\hline & & & & & 0,17 \\
\hline & & & & & 0,33 \\
\hline & & & & & 0,21 \\
\hline & & & & & 0,24 \\
\hline \multirow[t]{3}{*}{15} & Shahzadi, John [46] & Pakistan & The followership & 0,30 & 0,26 \\
\hline & & & & 0,50 & \\
\hline & & & Average & $\mathbf{0 , 3 9 5 7}$ & 0,3858 \\
\hline
\end{tabular}

Based on the outcomes of the calculation of the average score of followership as an independent variable (X) and dependent variable (Y), the average score of followership as a variable $(\mathrm{X})$ is 0.3957 , while the average score of followership as a variable $(\mathrm{Y})$ is of 0.3858 .

The author made a number of attempts to determine the interpretation of the mean value of followership, both as a variable (X) and as a variable (Y). The steps that the author takes are to perform calculations in the form of a score distribution for each variable $(\mathrm{X})$ and variable $(\mathrm{Y})$. First, the writer determines the range $(\mathrm{R})$ by subtracting the highest score from the lowest score. Second, the author determines the number of classes using the Sturgess formula, namely $(\mathrm{K})=1$ $+3.3 \log \mathrm{n}$. Third, the writer looks for the class interval (I) by dividing the range $(\mathrm{R})$ by the number of classes $(\mathrm{K})$. Through these steps, the interpretation table of the mean value of followership is obtained as follows.

Table 2. References for Interpretation of Mean Followership Values as Independent Variables (X)

\begin{tabular}{ccc}
\hline Class & Interval & Interpretation \\
\hline 1 & $0,138-0,229$ & Very Low \\
\hline 2 & $0,230-0,321$ & Low \\
\hline 3 & $0,323-0,414$ & Low Enough \\
\hline 4 & $0,415-0,506$ & High enough \\
\hline 5 & $0,507-0,598$ & High \\
\hline 6 & $0,599-0,690$ & Very high \\
\hline
\end{tabular}

The average followership score as the $\mathrm{X}$ variable is 0.3957 . It is in the 3rd class interval, which is between $0.323-0.414$, and is included in the Fairly Low category.

Table 3. Reference Interpretation of Mean Followership Value as Dependent Variable (Y)

\begin{tabular}{ccc}
\hline Class & Interval & Interpretation \\
\hline 1 & $0,010-0,132$ & Very low \\
\hline 2 & $0,133-0,255$ & Low \\
\hline 3 & $0,256-0,378$ & Enough \\
\hline 4 & $0,379-0,501$ & High \\
\hline 5 & $0,502-0,624$ & Very high \\
\hline
\end{tabular}

The average followership score as variable $\mathrm{Y}$ is 0.385833 . It is in the 4th class interval, which is $0.379-0.501$, and is included in the high category.

\section{DISCUSSIONS}

\section{A. Followership as an independent variable $(X)$}

There are two followership, namely active and passive. Active follower roles are interactive roles that individuals play that complement leadership to achieve group and organizational performance [52]. A follower view in which a follower-centered idea is at the epicenter of attention in the leadership writings. An engaged follower role can be defined as a person with the dream and sociable capability to perform satisfactorily with others holds the power of personality to thrive without brave level, and a desire to partake in team efforts for the attainment of some greater standard purpose $[53,54]$.

Leadership style and the quality of the relationship with the leader itself have an important position in a nursing career, as evidenced by the Journal of Nursing Management [55]. However, follower optimistic behavior, regarding the relationship between head and members and how follower functioning is interpreted, has not been included in the list of resources influencing well-being and inspiration. This is because job resources are defined as physical, social, or organizational aspects of work that can play a role in achieving work goals. It is members who must behave as followers to be able to meet these demands [56].

As later ones, we owe it to Kelley as the researcher who initiated a role-based approach to followers or organizational members in reviews on the topic of members or followers [11]. The ideal follower is someone who plays an active role in an organization as part of a common process in order to achieve the goals of the organization in which he works [14, 54, 57]. Followers are placed in a two-quadrant image to map followers. The two quadrants are the passive-active and independent-dependent quadrants and describe the follower model as actively participating and successfully demonstrating the strength of a courageous heart [14]. Followers work in two main dimensions: a) take the initiative to take a role, actively participate actively like a beginner in establishing a relationship with the leader; b) independent in critical thinking provides critical and constructive thinking and is able to manifest his thoughts by showing creativity and innovation and demonstrating the ability to lead himself. This type of follower is an example of an independent and active follower. This type is also able to convey proactive behavior, including being able to express concerns, ideas, suggestions, and problems with work with the aim of increasing organizational productivity [58]. 
Several studies have examined the relationship between the two follower behaviors and variables in terms of the philosophy of science. For example, studies analyzing member enthusiastic engagement and follower autonomic essential reflection [59,60], Mushonga and Torrance 2008), or previous and antecedent behaviors [61], Blanchard, Welbourne [10] in their attempt to validate the scale [14], also examined the relationship between the two proportions and several possible outcomes, particularly indicators of well-being and motivation at work. They found that follower active engagement was fully connected with intrinsic and extrinsic job satisfaction and affective and normative organizational commitment, while followers' independent critical thinking was negatively correlated with extrinsic and organizational career excitement normative commitment. In the evidence of the Italian Kelley scale [61], an influential approval correlation was found between follower active engagement and job satisfaction, and an insignificant relationship between followers' autonomic vital reflection and job satisfaction. With regard to behavioral and operational boundaries that emphasize active positive involvement of members and independent thinking of followers, and a mixture of all aspects of the two quadrants is positively related to work relationships. Furthermore, the more convincing relationship was follower active engagement and job satisfaction. While the relationship between active involvement and job satisfaction is the followers' independent critical thinking and outcome variables.

Studying following is complex because the role of followers is frequently unclear and unrestricted to understanding [62]. For this reasoning, the unverified hypothesis concerning followers' independent critical thinking is neither surprising nor discouraging. But conflicting results for this extent got here as well as in prior investigations warrant a rethinking of its meaning and value $[10,61]$. $\mathrm{f}$ we consider follower independent critical thinking as a visionary behavior such as organizational citizenship manners or sound, where the latter can be considered as the behavior closest to followers, forthcoming research can examine the inverse relationship of follower satisfaction independent critical thinking: job satisfaction can increase follower independent critical thinking as well as for other proactive behaviors [63]. Furthermore, it would be beneficial to examine the moderating effect of leader-member exchange or variables such as leader satisfaction on the relationship between follower independent critical thinking and job joy: if we consider follower independent critical thinking to be identical to sound behavior, the leader can hope that the result is intensely affected by the quality of the association with the leader [64].

In addition, courageous followers contribute to developing this exemplary leadership practice. That brave followership behavior has a powerful effect on exemplary leadership practices and will raise the manager's capacity to become good leaders is real. Leaders as right followers will also demonstrate outstanding leadership in their organizations. This fact supports the hypothesis showing that managers of public and private sector institutions, through self-reporting survey responses show standards as followers as well as leaders that reinforce theoretical notions from studies of other experimenters $[39,65,66]$. This finding also confirms the concept, that individuals lead and follow and true leadership has combined the deed of guiding and obeying [67]. Right follower learning influences the insight of obligation and responsibility-oriented behavior that leads to the growth of personal ethics $[68,69]$.

In addition, followers who are bold as a visionary behavior influence positive organizational results. A brave follower is a shape of visionary behavior that helps in creating followers to see their function with the leader as co-producer leader [70, 71]. Managers who adopt brave follower behavior create the institution better organized and can become the leaders of tomorrow. Therefore, research findings such as this one follow the audacious follower and may provide a broad view of leadership. This is in line with the concept that subordinates in follower positions have the capacity to demonstrate leadership. This type of upward leadership differs from a top-down leadership role [17, 72].

Proactive behavior guides to "taking the initiative, voicing concerns, taking ownership, and offering solutions before being asked by the leader" [17]. Proactive followers will show additional endeavor in deciding with their leader whether their obligations or the way they serve should be modified. As follower behavior becomes more proactive, the use of follower voice behavior (attempting to help the leader or group by constructively challenging the leader) [17] and function creation [73] increases. Proactive followers offer more involvement in additional-role manners such as civic benevolence (showing regard about or partaking responsibly in the political life of the leader's group or organization), generosity (trying to assist other members of his or her unit or organization), politeness, and interpersonal assistance [73]. They create proactive endeavors to affect their leaders by utilizing upward influence tactics such as logical convincing, touching appeal, consultation, personal appeal, and rightfulness [73]. In a condition where a follower sounds proactive follower behavior, it can be hoped that the leader feels positive about that follower. In the visions of the leader, followers will hold all the situational-specific knowledge and skills that the leader assumes are essential for accurate implementation. Followers who demonstrate proactive following behavior are sensed as benevolent and trustworthy members by the leader. In line with this argument, we posit that proactive behavior is positively related to leader trust [74].

\section{B. Followership as dependent variable ( $Y)$}

From the standpoint of an efficient institution, followership and effective leadership are equally important however, the benefits of followership have infrequently been studied [11]. Unit tentative leadership is totally connected to competence and followers and that competence and followers are positively related to accomplishment. This research fact is compatible with the results of prior investigations [75-78], revealing that joint unit members with heightened grades of competence and followers indicate high team performance. A Gallup Poll survey exposed that only $9 \%$ of workers are committed to 
working if the institution's leadership does not respect the individual benefits of its members; this ratio increases sharply to around $73 \%$ of managers prioritize employee benefits [79, 80]. Accordingly, this research suggests that corporations enforce team temporal leadership and concentrate on enhancing employee competence and engagement [81].

Employment growth is the method of reaching one's capabilities, significances, and interests with a career that can adjust these individual grades and fulfill personal requirements $[82,83]$. After securing a job by means of education and training, employees frequently accept additional job-specific training, to gradually attain their career objectives. In particular, workers with a firm reliance base are more possible to feel valued, resulting in more elevated success rates [84, 85]. In short, workers work to take authority of their professions, seek development, and enhance their employability, and wish their leaders to sustain their endeavors [86]. Managers can enhance their leadership mastery by way of training and counseling [87]. In addition, human resource programs such as education and training can also enhance worker competence and followership [88, 89]. Highperforming organizations must have sufficient mechanisms for worker career growth, with education and training as the primary focus. Consequently, companies are recommended to execute a team tentative leadership training program to develop leaders with team tentative leadership capabilities and to improve worker skills and follow-up through education and training.

Sociable exchange theory supplies the foundation for comprehending how followers' look at the aid bridges the affinity between proactive conduct and leader trust. Perceived follower help is defined as "a leader's general belief that followers of their work value their contributions and care about their well-being." It is an important element of their contextual environment in the definition of a leader and can be used by leaders as an indicator of followers' good or bad views. We argue that positive perceptions of followers in their proactive response may affect the follower approval that leaders feel that followers should care about their well-being [46]. Perceived follower approval can affect supervisor conduct. Perceived follower approval positively influences supervisors' trust grades to set higher-level goals, fulfill socioemotional needs and improve leaders' hopes that the organization will award endeavors on behalf of followers. Thus, perceived follower approval can cause a sense of responsibility to care about followers' well-being and to oblige them in reaching their goals [90].

\section{CONCLUSION}

The authors, from this an integrated literature review, examined the followership variable as an influencing variable $(\mathrm{X})$ and an affected variable (Y), arriving at two main conclusions: (1) followers as a variable $\mathrm{X}$ have the characteristics of being proactive, critical of the situation that occurs in their organization, dare to express their views and criticize the leader for the goodness and success of the organization with which he is affiliated, a score that is in the low enough category range indicates to the reader that the participation of followers has not yet received the attention of the leader to be given more space to contribute or because followers are generally thought of so think not to think because someone has already thought about it, (2) the follower as a $\mathrm{Y}$ variable is characterized by that the follower is the one to think about so that he only needs to be obedient, committed, perform well so that the leader provides opportunities to continue to grow with his organization and continue to develop develop their competencies through training designed by their leaders.

\section{REFERENCES}

[1] Baker, S.D., et al., The fluid nature of follower and leader roles. Followership: What is it and why do people follow, 2014. 73.

[2] Sy, T. and T. McCoy, Being both leaders and followers: Advancing a model of leader and follower role switching. Followership: What is it and why do people follow, 2014: p. 121-140.

[3] Kleiner, K., Rethinking leadership and followership: A student's perspective. Chap, 2008. 7: p. 89-94.

[4] Hughes, M., The leadership of organizational change. 2015: Routledge.

[5] Yung, C.T. and K.C. Tsai, Followership: An important partner of leadership. Business and Management Horizons, 2013. 1(2): p. 47-55.

[6] Bufalino, G., We need great "followers", not just great leaders: a brief questionnaire for followership development. Development and Learning in Organizations: An International Journal, 2018.

[7] Buchanan, E., Can there be leadership without followership? 2007.

[8] Prilipko, E.V., Advancing Leadership and Followership Education with a Leader-Follower Unity Model. Journal of Higher Education Theory and Practice, 2019. 19(3): p. $145-152$.

[9] Mahsud, R., G. Yukl, and G. Prussia, Leader empathy, ethical leadership, and relations- oriented behaviors as antecedents of leader- member exchange quality. Journal of Managerial Psychology, 2010.

[10]Blanchard, A.L., et al., Followership styles and employee attachment to the organization. The PsychologistManager Journal, 2009. 12(2): p. 111-131.

[11] Uhl-Bien, M., et al., Followership theory: A review and research agenda. The leadership quarterly, 2014. 25(1): p. 83-104.

[12] Shamir, B., From passive recipients to active coproducers: Followers' roles in the leadership process. Follower-centered perspectives on leadership: A tribute to the memory of James R. Meindl, 2007: p. 9-39.

[13] Somech, A. and M. Wenderow, The impact of participative and directive leadership on teachers' performance: The intervening effects of job structuring, decision domain, and leader-member exchange. Educational Administration Quarterly, 2006. 42(5): p. 746-772. 
[14] Kelley, R.E., The power of followership: How to create leaders people want to follow, and followers who lead themselves. 1992: Broadway Business.

[15]Benson, A.J., J. Hardy, and M. Eys, Contextualizing leaders' interpretations of proactive followership. Journal of Organizational Behavior, 2016. 37(7): p. 949-966.

[16]Blom, M. and M. Alvesson, Leadership On Demand: Followers as initiators and inhibitors of managerial leadership. Scandinavian Journal of Management, 2014. 30(3): p. 344-357.

[17] Carsten, M.K., et al., Exploring social constructions of followership: A qualitative study. The leadership quarterly, 2010. 21(3): p. 543-562.

[18] Junker, N.M. and R. Van Dick, Implicit theories in organizational settings: A systematic review and research agenda of implicit leadership and followership theories. The Leadership Quarterly, 2014. 25(6): p. 1154-1173.

[19]Leroy, H., et al., Authentic leadership, authentic followership, basic need satisfaction, and work role performance: A cross-level study. Journal of management, 2015. 41(6): p. 1677-1697.

[20] Oc, B. and M.R. Bashshur, Followership, leadership and social influence. The Leadership Quarterly, 2013. 24(6): p. 919-934.

[21] Sy, T., What do you think of followers? Examining the content, structure, and consequences of implicit followership theories. Organizational Behavior and Human Decision Processes, 2010. 113(2): p. 73-84.

[22] Milosevic, I., S. Maric, and D. Lončar, Defeating the toxic boss: The nature of toxic leadership and the role of followers. Journal of Leadership \& Organizational Studies, 2020. 27(2): p. 117-137.

[23] Oyetunji, C.O., The Relationship between Followership Style and Job Performance in Botswana Private Universities. International Education Studies, 2013. 6(2): p. 179-187.

[24]Pey, Y.S., et al., "Followership"-The Missing Puzzle in Educational Leadership Research. Sciences, 2021. 11(2): p. 904-923.

[25]Foley, T.J., Followership and student leadership: Exploring the relationship. Journal of Leadership, Accountability \& Ethics, 2015. 12(4).

[26] Perun, S.A., A Content Analysis Revealing MPA Students' Unquestioning Followership as their Ethical Stance and the Implications for Ethical Competence. Public Integrity, 2020. 22(5): p. 456-469.

[27]Jin, M.H., B. McDonald, and J. Park, Personorganization fit and turnover intention: Exploring the mediating role of employee followership and job satisfaction through conservation of resources theory. Review of Public Personnel Administration, 2018. 38(2): p. 167-192.

[28] Tak, J., J. Seo, and T. Roh, The influence of authentic leadership on authentic followership, positive psychological capital, and project performance: testing for the mediation effects. Sustainability, 2019. 11(21): p. 6028.
[29] Greene, M.T. and S. Saint, Followership characteristics among infection preventionists in US hospitals: results of a national survey. American journal of infection control, 2016. 44(3): p. 343-345.

[30] Travis, S.A., Physicians and rounding teams: a study of followership in the medical profession. 2015: Indiana Wesleyan University.

[31] Gatti, P., C. Ghislieri, and C.G. Cortese, Relationships between followers' behaviors and job satisfaction in a sample of nurses. PloS one, 2017. 12(10): p. e0185905.

[32] Kang, J.-w., J.-h. Heo, and J.-h. Kim, The followership of hotel employees and the relationship between occupational burnout, job stress, and customer orientation: Targeting the hotel service providers at luxury hotels. Tourism and Hospitality Research, 2016. 16(4): p. 345-358.

[33] Jin, M., B. McDonald, and J. Park, Followership and job satisfaction in the public sector: The moderating role of perceived supervisor support and performance-oriented culture. International Journal of Public Sector Management, 2016.

[34] Tisserand, L., High fidelity simulation: From simulation to debrief, assessing leadership and followership management. Hacettepe University Journal of Education, 2018. 33: p. 134-155.

[35] Gordon, L.J., et al., Leadership and followership in the healthcare workplace: exploring medical trainees' experiences through narrative inquiry. BMJ open, 2015. 5(12): p. e008898.

[36] Sculli, G.L., et al., Effective followership: a standardized algorithm to resolve clinical conflicts and improve teamwork. Journal of Healthcare Risk Management, 2015. 35(1): p. 21-30.

[37] du Plessis, M. and A.B. Boshoff, Authentic leadership, followership, and psychological capital as antecedents of work engagement. Journal of Psychology in Africa, 2018. 28(1): p. 26-32.

[38] Stegmann, S., et al., Getting older and living up to implicit followership theories: Implications for employee psychological health and job attitudes. Journal of Applied Social Psychology, 2020. 50(2): p. 65-81.

[39] Ghias, W., S. Hassan, and M.T. Masood, Does Courageous Followership contribute to Exemplary Leadership Practices: Evidence from Pakistan? NUML International Journal of Business \& Management, 2018. 13(1): p. 11-21.

[40]Li, H., et al., Exploring the relationship between leadership and followership of Chinese project managers. International Journal of Managing Projects in Business, 2019.

[41] Yuan, C.-C. and S.-H. Lo, Relationship among team temporal leadership, competency, followership, and performance in taiwanese pharmaceutical industry leaders and employees. Journal of Career Development, 2018. 45(3): p. 227-238.

[42] Kong, M., et al., Implicit followership theory to employee creativity: The roles of leader-member exchange, self- 
efficacy and intrinsic motivation. Journal of Management \& Organization, 2019. 25(1): p. 81-95.

[43]Kong, M., et al., Select the Mr. Right: the interaction effect between implicit leadership and implicit followership on employees' workplace behaviors. Personnel Review, 2020.

[44] Fontoura, P. and A. Coelho, The impact of supply chain leadership and followership on CSR: an empirical study about a Portuguese energy supplier. 2020.

[45] Pujiastuti, E.T., et al., Influence of Leadership, Loyalty, and Followership on Team Performance of PT Gaharu Galangan International. International Journal of Marine Engineering Innovation and Research, 2020. 5(2).

[46] Shahzadi, G., et al., Followership behavior and leaders' trust: Do political skills matter? Pakistan Journal of Commerce and Social Sciences, 2017. 11(2): p. 653-670.

[47]LePine, M.A., et al., Turning their pain to gain: Charismatic leader influence on follower stress appraisal and job performance. Academy of Management Journal, 2016. 59(3): p. 1036-1059.

[48] Amin, B., H. Hamidah, and K. Gunawan, The influence of transformational leadership, power distance, and followership on the decision making capability. Management Science Letters, 2020. 10(16): p. 3915-3922.

[49] Jin, M.H., et al., Making public service motivation count for increasing organizational fit: The role of followership behavior and leader support as a causal mechanism. International Review of Administrative Sciences, 2019. 85(1): p. 98-115.

[50] Jia, J., et al., Paradoxical leadership incongruence and Chinese individuals' followership behaviors: moderation effects of hierarchical culture and perceived strength of human resource management system. Asian Business \& Management, 2018. 17(5): p. 313-338.

[51]Bligh, M.C., Followership and follower-centred approaches. The Sage handbook of leadership, 2011: p. 425-436.

[52] Howell, J. and D. Costley, Understanding effective behaviors for leadership. 2006, Upper Saddle River, NJ: Pearson Prentice Hall.

[53] Cruickshank, V., Followership in the school context. Open Journal of Leadership, 2017. 6: p. 95-103.

[54] Kelley, R.E., In praise of followers. 1988: Harvard Business Review Case Services.

[55] Morton, J.L. and K. Hyrkas, Management and leadership at the bedside. 2012, Wiley Online Library.

[56] Demerouti, E., et al., The job demands-resources model of burnout. Journal of Applied psychology, 2001. 86(3): p. 499.

[57]Kelley, R., Rethinking Followership. Teoksessa Art of Followership: How Great Followers Create Great Leaders and Organizations, toim. Riggio, RE-Chaleff, I.Lipman-Blumen, I., 5-14. 2008, Wiley, Hoboken, NJ, US.

[58] Morrison, E.W., Employee voice behavior: Integration and directions for future research. Academy of Management annals, 2011. 5(1): p. 373-412.

[59] Tanoff, G.F. and C.B. Barlow, Leadership and followership: Same animal, different spots? Consulting
Psychology Journal: Practice and Research, 2002. 54(3): p. 157.

[60] Mushonga, S. and C. Torrance, Assessing the relationship between followership and the big five factor model of personality. Review of Business Research, 8 (6), 185-193. 2008.

[61] Gatti, P., et al., A contribution to the Italian validation of Kelley's followership questionnaire. 2014.

[62] Parker, S.K., That is my job' How employees' role orientation affects their job performance. Human Relations, 2007. 60(3): p. 403-434.

[63] Williams, L.J. and S.E. Anderson, Job satisfaction and organizational commitment as predictors of organizational citizenship and in-role behaviors. Journal of management, 1991. 17(3): p. 601-617.

[64]Detert, J.R. and E.R. Burris, Leadership behavior and employee voice: Is the door really open? Academy of management journal, 2007. 50(4): p. 869-884.

[65]Dixon, E.N., An exploration of the relationship of organizational level and measures of follower behaviors. 2003, The University of Alabama in Huntsville.

[66] Martin, R., A review of the literature of the followership since 2008: The importance of relationships and emotional intelligence. Sage Open, 2015. 5(4): p. 2158244015608421.

[67] Tsakeni, M. and L.C. Jita, Followership and sustainability of school leadership for Science and Mathematics: A distributive perspective. Journal of Education (University of KwaZulu-Natal), 2017(69): p. 237-256.

[68] Schwab, K.W., Teaching and Learning Courageous Followership: An Action Research Study. 2017, University of the Incarnate Word.

[69]Umer, H.K., The Relational Theory of the LeadershipFollowership Process: Perceptions of Leaders and Followers in the Ethiopian Kale Heywet Church. 2019: Biola University.

[70] Tolstikov-Mast, Y., Global followership: The launch of the scholarly journey, in Advances in global leadership. 2016, Emerald Group Publishing Limited.

[71] Tchoumi, B., Why do you "talk" like that? The accented voices of Black African immigrants in school leadership. 2020, Morgan State University.

[72] Almeida, T., N.C. Ramalho, and F. Esteves, Can you be a follower even when you do not follow the leader? Yes, you can. Leadership, 2021. 17(3): p. 336-364.

[73] Lapierre, L.M. and N. Bremner, Reversing the lens: How can followers influence their leader's behavior? 2010.

[74] Bremner, N., The Influence of Follower Behaviour on Leaders' Trust in Followers. 2011: University of Ottawa (Canada).

[75] Dundis, S., Building More Effective Virtual Teams: An Examination of the Task Variable in Group ProblemSolving. International Journal on E-Learning, 2002.

[76] Kim, C., Followership characteristics among US Federal Government employees. Korean Journal of Policy Studies, 2011. 26.

[77] Fey, C.F. and I. Björkman, The effect of human resource management practices on MNC subsidiary performance 
in Russia. Journal of international business studies, 2001. 32(1): p. 59-75.

[78] Aungsuroch, Y., J. Gunawan, and M.L. Fisher, Competence-Based Human Resource Management, in Redesigning the Nursing and Human Resource Partnership. 2022, Springer. p. 15-30.

[79] Rath, T. and B. Conchie, Strengths based leadership: Great leaders, teams, and why people follow. 2008: Simon and Schuster.

[80]Khuwaja, U., et al., Leadership and employee attitudes: The mediating role of perception of organizational politics. Cogent Business \& Management, 2020. 7(1): p. 1720066.

[81] Nikolova, I., W. Schaufeli, and G. Notelaers, Engaging leader-Engaged employees? A cross-lagged study on employee engagement. European Management Journal, 2019. 37(6): p. 772-783.

[82] Creed, P.A. and M. Hood, Disengaging from unattainable career goals and reengaging in more achievable ones. Journal of Career Development, 2014. 41(1): p. 24-42.

[83] Callanan, G.A., D.F. Perri, and S.M. Tomkowicz, Career management in uncertain times: Challenges and opportunities. The Career Development Quarterly, 2017. 65(4): p. 353-365.

[84] Creed, P., J. Macpherson, and M. Hood, Predictors of "new economy" career orientation in an Australian sample of late adolescents. Journal of Career Development, 2011. 38(5): p. 369-389.

[85] Hood, M. and P.A. Creed, Globalisation: Implications for Careers and Career Guidance, in International Handbook of Career Guidance. 2019, Springer. p. 477495.

[86]Lu, C.-q., J.-w. Sun, and D.-y. Du, The relationships between employability, emotional exhaustion, and turnover intention: The moderation of perceived career opportunity. Journal of Career Development, 2016. 43(1): p. 37-51.

[87] Radstaak, J., Training and coaching of transformational leadership. Inaugural-Dissertation, der Westfälischen Wilhelms-Universität zu Münster (Westf.), 2008.

[88]Guest, D.E., Human resource management and performance: a review and research agenda. International journal of human resource management, 1997. 8(3): p. 263-276.

[89] Kim, C., Followership in the US federal government: A missing link between participative leadership and organizational performance. 2011, Rutgers UniversityGraduate School-Newark.

[90]Bailey, J., The effects of hospital unit nurse leaders' perceived follower support on nursing staff performance outcomes. 2014: Georgia State University.
Herdian Herdian was born in Palembang on April 30, 1986. In 2008 he obteined s1 degree in Universitas Lampung, faculty of Education. In 2010 he obtained a magister degree in master in mathematics Education from Universitas Pendidikan Indonesia.

\section{Contribution of Individual Authors to the Creation of a Scientific Article (Ghostwriting Policy)}

Ridwan, Sulpakar and M.A Rifki Z carried out the analysis the articles

Albert Maiydiantoro and Tubagus Ali Puja Kesuma has searched and collected articles.

Sudjarwo and Hasan Hariri were responsible for the content analysis.

\section{Sources of Funding for Research Presented in a Scientific} Article or Scientific Article Itself

No any parties funded this articles for publications

\section{Creative Commons Attribution License 4.0 (Attribution 4.0 International, CC BY 4.0)}

This article is published under the terms of the Creative Commons Attribution License 4.0

https://creativecommons.org/licenses/by/4.0/deed.en_US 